\title{
Astragalus saponins affect proliferation, invasion and apoptosis of gastric cancer BGC-823 cells
}

\author{
Tao Wang ${ }^{1}$, Xiaoyan Xuan², Min Li ${ }^{2}$, Ping Gao ${ }^{1}$, Yuling Zheng ${ }^{3}$, Wenqiao Zang ${ }^{2 *}$ and Guogiang Zhao ${ }^{2 *}$
}

\section{Abstract}

Background: Astragalus memebranaceus is a traditional Chinese herbal medicine used in treatment of common cold, diarrhea, fatigue, anorexia and cardiac diseases. Recently, there are growing evidences that Astragalus extract may be a potential anti-tumorigenic agent. Some research showed that the total saponins obtained from Astragalus membranaceus possess significant antitumorigenic activity. Gastric cancer is one of the most frequent cancers in the world, almost two-thirds of gastric cancer cases and deaths occur in less developed regions. But the effect of Astragalus membranaceus on proliferation, invasion and apoptosis of gastric cancer BGC-823 cells remains unclear.

Methods: Astragalus saponins were extracted. Cells proliferation was determined by CCK-8 assay. Cell cycle and apoptosis were detected by the flow cytometry. Boyden chamber was used to evaluate the invasion and metastasis capabilities of BGC-823 cells. Tumor growth was assessed by subcutaneous inoculation of cells into BALB/c nude mice.

Results: The results demonstrated that total Astragalus saponins could inhibit human gastric cancer cell growth both in vitro and in vivo, in additional, Astragalus saponins deceased the invasion ability and induced the apoptosis of gastric cancer BGC-823 cells.

Conclusions: Total Astragalus saponins inhibited human gastric cancer cell growth, decreased the invasion ability and induced the apoptosis. This suggested the possibility of further developing Astragalus as an alternative treatment option, or perhaps using it as adjuvant chemotherapeutic agent in gastric cancer therapy.

Keywords: Gastric cancer, Proliferation, Invalsion, Apoptosis

\section{Introduction}

Astragalus memebranaceus (AST) is a traditional Chinese herbal medicine used in treatment of common cold, diarrhea, fatigue, anorexia and cardiac diseases [1-4]. In recent years, radix Astragalus membranaceus has also been used to ameliorate the side effects of cytotoxic antineoplastic drugs [51. The active pharmacological constituents of radix Astragalus membranaceus include various polysaccharides, saponins and flavonoids [6]. Among these, Astragalus polysaccharides have been most widely studied, mainly on their immunopotentiating properties like stimulation of murine B-cell proliferation and cytokine

\footnotetext{
* Correspondence: zangwenqiao@sina.com; zhaogq@zzu.edu.cn

${ }^{2}$ Department of Microbiology and Immunology, College of Basic Medical Sciences, Zhengzhou University, Zhengzhou, People's Republic of China Full list of author information is available at the end of the article
}

production [7]. Apart from these, clinical studies also showed that Astragalus polysaccharides could counteract the side effects of chemotherapeutic drugs, such as a significant reduction in the degree of myelosuppression in cancer patients [8]. Recently, there are growing evidences that Astragalus extract may be a potential antitumorigenic agent. For instance, hepatocarcinogenesis could be prevented in rats fed with the aqueous extract of Astragalus, which is mainly composed of Astragalus polysaccharides [9]. There are also reports that describe the potentiating effect of Astragalus extract in recombinant interleukin-2-generated lymphokine-activated cells upon the anti-tumorigenic action of drugs against murine renal carcinoma [10]. Saponins isolated from radix
C Biomed Central

(C) 2013 Wang et al.; licensee BioMed Central Ltd. This is an Open Access article distributed under the terms of the Creative Commons Attribution License (http://creativecommons.org/licenses/by/2.0), which permits unrestricted use, distribution, and reproduction in any medium, provided the original work is properly cited. The Creative Commons Public Domain Dedication waiver (http://creativecommons.org/publicdomain/zero/1.0/) applies to the data made available in this article, unless otherwise stated. 
Astragalus membranaceus consist of astragalosides (IVIII) and some of their isomer isoastragalosides (I,II and IV) $[11,12]$. Similar to the polysaccharides obtained from the same herb, Astragalus saponins have been found to possess immunomodulating effects. The pure isolated saponin astragaloside IV could increase murine $\mathrm{B}$ and $\mathrm{T}$ cell proliferation [13] and possess cardioprotective properties $[14,15]$. Some research showed that the total saponins obtained from Astragalus membranaceus (AST) possessed significant antitumorigenic activity in HT-29 human colon cancer cells and tumor xenograft [16]. AST suppressed cancer cell growth by inhibiting proliferation through phase-specific cell cycle arrest and promotion of caspasedependent apoptosis. In nude mice xenograft, the AST induced reduction in tumor volume was comparable with that produced by the conventional chemotherapeutic drug 5-fluorouracil (5-FU), of which the side effects (including mortality) associated with the drug combo 5-FU 1 oxaliplatin could be largely alleviated when AST was used along with 5-FU in replacement of oxaliplatin [17].

Gastric cancer is one of the most frequent cancers in the world, almost two-thirds of gastric cancer cases and deaths occur in less developed regions. Gastric cancer is a significant cancer burden currently and be one of the key issues in cancer prevention and control strategy in China. But the effect of Astragalus membranaceus on proliferation, invasion and apoptosis of gastric cancer BGC-823 cells remains unclear. In the present study, we investigated the effect of Astragalus saponins on proliferation, invasion and apoptosis of gastric cancer BGC-823 cells.

\section{Materials and methods Materials}

Radix Astragalus membranaceus had been obtained from the province of Henan, China. The authenticity and quality of the crude herb were then tested in the Quality Assurance Laboratory, The First Affiliated Hospital of Henan University of TCM. Antibodies were from Santa CruzBiotechnology, USA. The human gastric cancer BGC-823 cell line was purchased from the Chinese Academy of Sciences Cell Bank. All cells were cultured in DMEM (Gibco, USA) supplemented with $10 \%$ fetal bovine serum (Gibco, USA) and grown in a $37^{\circ} \mathrm{C}, 5 \%$ $\mathrm{CO}_{2}$ incubator.

\section{Preparation of AST extract}

Astragalus saponins were extracted according to the method of $\mathrm{Ma}$ et al. [18] with slight modifications. In brief, $500 \mathrm{~g}$ of crude herb was refluxed with $2 \%$ potassium hydroxide in methanol for $1 \mathrm{~h}$. Butan-1-ol was added to the reconstituted residue from above for phase separation to obtain total saponins. The dried and lyophilized AST powder $(0.6 \% \mathrm{w} / \mathrm{w})$ was reconstituted in ultrapure water to form a $10 \mathrm{mg} / \mathrm{ml}$ stock and stored at $-20^{\circ} \mathrm{C}$.

\section{CCK-8 assay}

The cells in the logarithmic phase of growth were seeded in 96-well plates at a cell density of $5 \times 10^{4} /$ well. Cells were cultured at $37^{\circ} \mathrm{C}$ in $5 \% \mathrm{CO} 2$. After 12 hours, replace medium containing $0 \mu \mathrm{g} / \mathrm{ml}, 20 \mu \mathrm{g} / \mathrm{ml}, 40 \mu \mathrm{g} / \mathrm{mland}$ $80 \mu \mathrm{g} / \mathrm{ml}, 0 \mu \mathrm{g} / \mathrm{ml}$ as the control. after $0 \mathrm{~h}<24 \mathrm{~h} 、 48 \mathrm{~h}$. $72 \mathrm{~h}, 10 \mu \mathrm{L}$ CCK-8 were mixed. Cells were cultured at $37^{\circ} \mathrm{C}$ in $5 \%$ for 3 hours, and then optical density was measured at $450 \mathrm{~nm}$. All experiments were performed in triplicate.

\section{Cell-cycle analysis}

For cell cycle analysis by flow cytometry (FCM), cells in the logarithmic phase of growth were harvested by trypsinization, washed with PBS, fixed with $75 \%$ ethanol overnight at $4{ }^{\circ} \mathrm{C}$ and incubated with RNase at $37^{\circ} \mathrm{C}$ for $30 \mathrm{~min}$. Nuclei were stained with propidium iodide for $30 \mathrm{~min}$. A total of $10^{4}$ nuclei were examined in a FACS Calibur Flow Cytometer (Becton Dickinson, Franklin Lakes, NJ, USA). All experiments were performed in triplicate.

\section{Transwell invasion assay}

Transwell filters (Costar, USA) were coated with matrigel $(3.9 \mu \mathrm{g} / \mu \mathrm{l}, 60-80 \mu \mathrm{l})$ on the upper surface of the polycarbonic membrane $(6.5 \mathrm{~mm}$ in diameter, $8 \mu \mathrm{m}$ pore size). After $30 \mathrm{~min}$ of incubation at $37^{\circ} \mathrm{C}$, the matrigel solidified and served as the extracellular matrix for tumor cell invasion analysis. Cells transfected were harvested in $100 \mu \mathrm{l}$ of serum free medium and added to the upper compartment of the chamber. The cells that had migrated from the matrigel into the pores of the inserted filter were fixed with $100 \%$ methanol, stained with hematoxylin, mounted, and dried at $80^{\circ} \mathrm{C}$ for $30 \mathrm{~min}$. The number of cells invading the matrigel was counted from three randomly selected visual fields, each from the central and peripheral portion of the filter, using an inverted microscope at $100 \times$ magnification. All experiments were performed in triplicate.

\section{Apoptosis assay}

The Annexin V-FITC/PI Apoptosis Detection Kit I (Abcam, USA) was used to detect and quantify apoptosis by flow cytometry. In brief, cells in the logarithmic phase of growth were harvested in cold PBS and collected by centrifugation for $5 \mathrm{~min}$ at $1000 \times \mathrm{g}$. Cells were resuspended at a density of $1 \times 10^{6}$ cells $/ \mathrm{ml}$ in $1 \times$ binding buffer, stained with FITC-labeled annexin V for $5 \mathrm{~min}$ and immediately analyzed in a FACScan Flow Cytometer (Becton Dickinson). Data were analyzed by Cell Quest software. Tests were repeated in triplicate. 


\section{Nude mouse tumor xenograft model}

Fifteen immunodeficient female BALB/C nude mice, 56 weeks old were purchased from the Experimental Animal Center of the Henan province, China, They were bred under aseptic conditions and maintained at constant humidity and temperature, according to standard guidelines under a protocol approved by Zhengzhou University. Mice in the different groups were subcutaneously injected in the dorsal scapular region with the BGC-823 cells. After transplantation, the skin was closed and the mice were divided randomly into three groups (five mice per group). In 2 days, AST (100 mg/kg body weight) (Group1) and AST (200 mg/kg body weight) (Group2) [15] were administered once a day. PBS was administered as the control group. Primary tumors were allowed to develop for 28 days. The tumors formed were measured with a caliper every 7 days, and tumor volume was calculated using the formula: volume $=\pi$ (length $\times$ width $\left.^{2}\right) / 6$. Tumors were harvested after 4 weeks.

\section{Statistical analysis}

SPSS17.0 was used for statistical analysis. One-way analysis of variance (ANOVA) and the $\chi 2$ test were used to analyze the significance between groups. Multiple comparisons between the parental and control vector groups were made using the Least Significant Difference test when the probability for ANOVA was statistically significant. All data represent mean \pm SD. Statistical significance was set at $p<0.05$.

\section{Results}

Astragalus saponins inhibited proliferation of gastric cancer BGC-823 cells

CCK-8 assay was used to measure the cell growth and viability of BGC-823 cells. The effects of Astragalus saponins on proliferation of gastric cancer BGC-823 cells were determined. As shown in Figure 1A, Compared to the control, Astragalus saponins inhibited proliferation of BGC-823 cells at a dose- and time-dependent manner. These results suggested that Astragalus saponins might function as a tumor suppressor in BGC-823 in vitro.

\section{Astragalus saponins induced G1 arrest in BGC-823 cells}

The cell cycle distribution was analyzed by flow cytometry. The fractions of BGC-823 cells in the G0/G1 phase of the cell cycle in the $0 \mu \mathrm{g} / \mathrm{ml}, 20 \mu \mathrm{g} / \mathrm{ml}, 40 \mu \mathrm{g} / \mathrm{ml}$, $80 \mu \mathrm{g} / \mathrm{ml}$ Astragalus saponins groups were $55.99 \%$, $65.44 \%, 70.89 \%$, and $78.82 \%$ respectively (Figure $1 \mathrm{~B}$ ). These results indicated that Astragalus saponins induced cell cycle arrest in the G0/G1 phase, delayed the progression of the cell cycle, and inhibited cell proliferation.

\section{Astragalus saponins decreased the invasive and migration ability of BGC-823 cells}

Transwell invasion assay was used to evaluate the impact of Astragalus saponins on cell invasion and migration. BGC-823 cells were treated with $0 \mu \mathrm{g} / \mathrm{ml}, 20 \mu \mathrm{g} / \mathrm{ml}$, $40 \mu \mathrm{g} / \mathrm{ml}, 80 \mu \mathrm{g} / \mathrm{ml}$ Astragalus saponins, and then placed in a Transwell chamber. The number of Astragalus saponins treated BGC-823 cells migrating through the matrigel was significantly lower $(p<0.05)$ than those of the $0 \mu \mathrm{g} / \mathrm{ml}$ Astragalus saponins group (the control group), (Figure 2). The effect was more obvious for $80 \mu \mathrm{g} / \mathrm{ml}$ Astragalus saponins. These results demonstrated that Astragalus saponins inhibited the invasive ability of BGC823 cells in vitro.

\section{Astragalus saponins induced apoptosis of BGC-823 cells} BGC-823 cells apoptosis was measured by flow cytometry. Statistically significant $(p<0.05)$ increases in annexin $\mathrm{V}+$ apoptotic cells were observed in $20 \mu \mathrm{g} / \mathrm{ml}(6.53 \pm$ $0.62 \%), 40 \mu \mathrm{g} / \mathrm{ml}(12.14 \pm 0.69 \%)$ and $80 \mu \mathrm{g} / \mathrm{ml}(18.2 \pm$
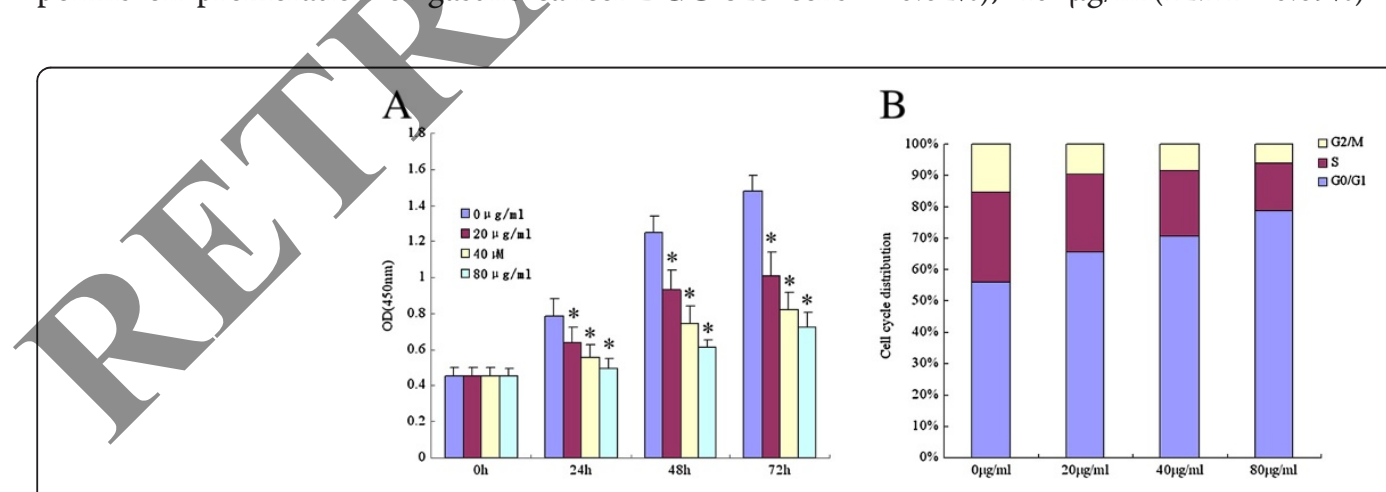

Figure 1 Effect of Astragalus saponins on proliferation and cell cycle of BGC-823 cells. A. Astragalus saponins inhibited proliferation of BGC-823 cells. Cells were treated with, $20 \mu \mathrm{g} / \mathrm{ml}, 40 \mu \mathrm{g} / \mathrm{ml}$, and $80 \mu \mathrm{g} / \mathrm{ml}$ Astragalus saponins, $0 \mu \mathrm{g} / \mathrm{ml}$ as a control, and cell proliferation was assessed using the CCK8 assay. Data are presented as the mean of triplicate experiments. The growth inhibitory effect of the Astragalus saponins was time and dose dependent, with the maximum inhibition detected $72 \mathrm{~h}$ after treatment. *Significant difference $(p<0.05)$. B. Astragalus saponins impaired cell cycle progression in BGC-823 cells. Cell cycle distribution was analyzed by flow cytometry. Data are presented as the mean of triplicate experiments. Administration of Astragalus saponins significantly increased the percentage of cells in the G0/G1 phase, and significantly decreased the $S$ and G2/M phase fractions. 


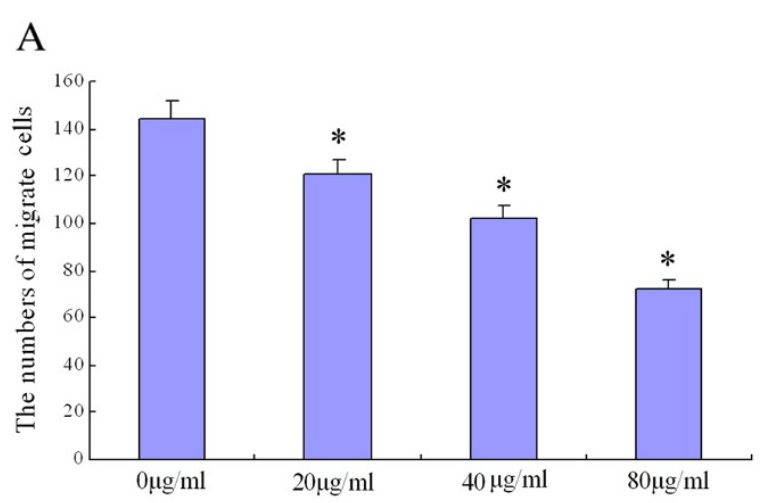

\section{B}
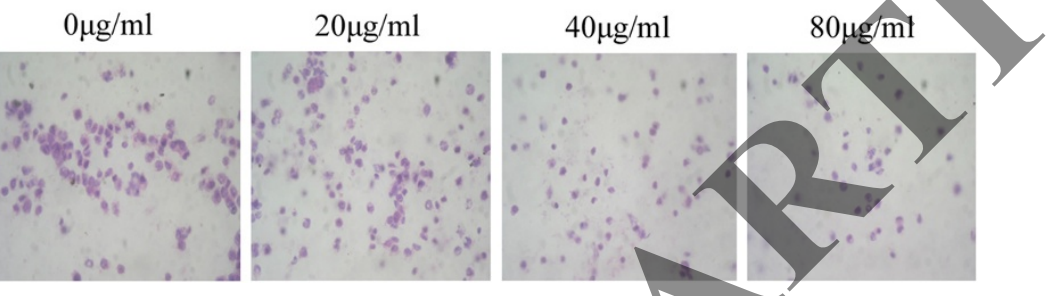

Figure 2 Astragalus saponins decreased the invasion and migration ability of BGC-823 cells. A. BGC-823 cell invasion was determined using the transwell invasion assay, which measures the number of cells that migrate through the matrigel into the lower surface of the polycarbonic membrane (100x). Data are presented as the mean of triplicate experiments. B. Cell invasion decreased significantly $\left.{ }^{*} p<0.05\right)$ in a dose-dependent manner in Astragalus saponins -treated cells compared with the control group.

0.79\%)Astragalus saponins-treated BGC-823 cell lines compared to control group $(3.56 \pm 0.45 \%)$ (Figure $3 \mathrm{~A})$. These results demonstrated that Astragalus saponins induced apoptosis of BGC-823 cells in vitro.

\section{Astragalus saponins inhibited gastric cancer xenograft growth}

Because Astragalus saponins play an important role in cell survival, we performed a proof-of-principle experiment using a BGC-823 cell xenograft model. As shown in Figure 3B, a significant decrease in tumor volume was observed in the Astragalus saponins -treated group
$(\mathrm{P}<0.05)$. These findings further suggest the therapeutic potential of Astragalus saponins for the gastric cancer.

\section{Discussion}

Despite recent advancement in understanding the carcinogenic processes of gastric cancer, the increasing incidence and relatively low remission rate of chemotherapy have urged the scientific community to establish more effective treatment regimens by adopting novel and innovative approaches. The discovery and use of active medicinal compounds from herbal/natural sources have provided alternative treatment choices for patients $[19,20]$.
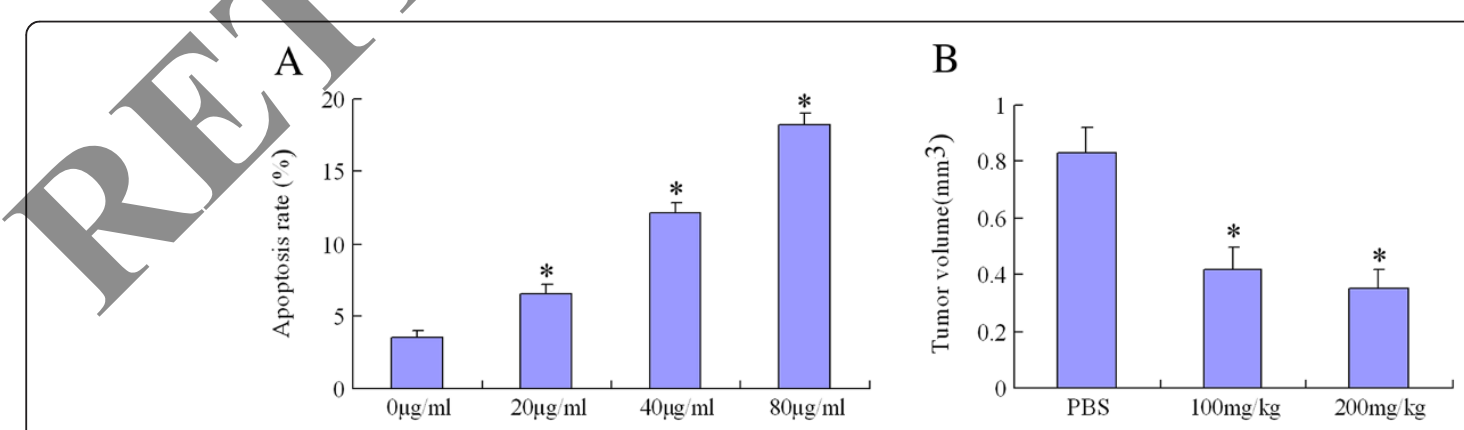

Figure 3 BGC-823 cell apoptosis and xenograft tumor experiment. A. Astragalus saponins induced apoptosis in BGC-823 cells. Cell apoptosis was analyzed by flow cytometry. Statistically significant $\left({ }^{*} p<0.05\right)$ increases in annexin $V+$ apoptotic cells were observed in Astragalus saponins-treated BGC-823 cells compared to controls. Data are presented as the mean of triplicate experiments. B. BGC-823 cell xenograft tumor experiment. Injection of Astragalus saponins inhibited tumor growth in a BGC-823 xenograft model compared with the blank control group. *Significant difference $(p<0.05)$. 
Tumor metastasis starts with breakdown of epithelial integrity, followed by malignant cells invading into the surrounding stroma and lymphovascular space, by which tumor cells travel to distant target organs. Some researchers showed that Ezrin, HER2 and c-MET abnormal expression were related to the poor prognosis of gastric adenocarcinoma [21-23].

Astragalus membranaceus (Radix Astragali) has a long history of medicinal use in Chinese herbal medicine. It has been formulated as an ingredient of herbal mixtures to treat patients with deficiency in vitality, which symptomatically presents with fatigue, diarrhea and lack of appetite. Radix Astragali is also commonly used as immunomodulating agent to stimulate the immune system of immunodeficient patients. Moreover, it has been reported that herbal formulations containing Radix Astragali and some of its constituents could produce hepatoprotective [24], antiviral [25] and antioxidative effects [26]. Recently, evidence from various animal and clinical studies has demonstrated that Radix Astragali may possess anticarcinogenic property [27], which could attenuate the systemic side effects of conventional antineoplatic drugs [28].

In the present study, we have shown that the total saponins obtained from radix Astragalus membranaceus could be established as effective chemotherapeutic agent to suppress gastric cancer cell growth through promotion of apoptosis and inhibition of cell proliferation. This is the first report that clearly characterizes the antitumor properties of Astragalus saponins in gastric cancer cells and tumor xenograft.

Astragalus saponins affect proliferation, inyasion and apoptosis of gastric cancer BGC-823 cells. The mechanisms remain unclear. Some researchers considered the anticancer properties of Astragalus species could be explained by immunological mechanisms on the basis of the results obtained in a study with urological neoplasm cells and bladder murine carcinomas, Rittenhouse et al. [29] reported that A. membranaceus may exert its antitumor activity by abolishing tumor-associated macrophage suppression. The potentiation of the natural killer cytotoxicity of peripheral blood mononuclear cells in patients with systemic lupus erythematosus was demonstrated by Zbao [30] using an enzyme-release assay. The activity was increased in the samples of healthy donors and patients with the pathology. The release of a natural killer cytotoxic factor by peripheral blood mononuclear cells was higher in the control group, and the levels of that factor correlated well with natural killer activity, and correlated negatively with the clinical effect.

Others thought the anticancer properties of Astragalus was associated with RSK2. The Ras-ERKs-RSK2 pathway regulates cell proliferation, survival, growth, motility and tumorigenesis. RSK2 is a direct substrate kinase of ERKs and, functionally speaking, is located between ERKs and its target transcription factors [31]. Studies have demonstrated that the total cellular RSK2 protein level is significantly higher in cancer cells compared with normal tissues and premalignant cell lines [32-37].

In summary, we have demonstrated in the present study that total Astragalus saponins could inhibit human gastric cancer cell growth both in vitro and in vivo. This suggested the possibility of further developing Astragalus as an alternative treatment option, or perhaps using it as adjuvant chemotherapeutic agent in gastric cancer therapy.

\section{Conclusions}

Total Astragalus saponins could inhibit human gastric cancer cell growth both in vitro and in vivo. This suggested the possibility of further developing Astragalus as an alternative treatment option, or perhaps using it as adjuvant chemotherapeutic agent in gastric cancer therapy.

\section{Competing interests}

The authors declare that they have no competing interests.

Authors' contribution

$X Y X, M L$ and PG. conceived of the study, and participated in its design and coordination and helped to draft the manuscript. WQZ and GQZ: carried out part of experiments and wrote the manuscript. YLZ performed the statistical All authors read and approved the final manuscript.

\section{Acknowledgments}

This study was supported by Henan province science and technology research projects (122102310550).

\section{Author details}

${ }^{1}$ Department of Hemato-tumor, The First Affiliated Hospital of Henan University of TCM, Zhengzhou, People's Republic of China. ${ }^{2}$ Department of Microbiology and Immunology, College of Basic Medical Sciences, Zhengzhou University, Zhengzhou, People's Republic of China. ${ }^{3}$ Henan University of TCM, Zhengzhou, People's Republic of China.

Received: 5 October 2013 Accepted: 22 October 2013

Published: 24 October 2013

\section{References}

1. Di N, Liu F-N, Miao Z-F, Du Z-M, Xu H-M: Astragalus extract inhibits destruction of gastric cancer cells to mesothelial cells by anti-apoptosis. World J Gastroenterol 2009, 15(5):570-577.

2. Sun Y, Jin L, Wang T, Xue J, Liu G, Li X, et al: Polysaccharides from astragalus membranaceus promote phagocytosis and superoxide anion (O2-) production by coelomocytes from sea cucumber apostichopus japonicus in vitro. Comp Biochem Physiol C Toxicol Pharmacol 2008, 147:293-298.

3. Wang PC, Zhang ZY, Zhang J, Tong TJ: Two isomers of HDTIC isolated from astragali radix decrease the expression of p16 in 2BS cells. Chin Med J (Engl) 2008, 121:231-235.

4. Yuan C, Pan X, Gong Y, Xia A, Wu G, Tang J, Han X: Effects of astragalus polysaccharides (APS) on the expression of immune response genes in head kidney, gill and spleen of the common carp, cyprinus carpio L. Int Immunopharmacol 2008, 8:51-58.

5. Zee-Cheng RK: Shi-quan-da-bu-tang (ten significant tonic decoction), SQT. Apotent Chinese biological response modifier in cancer immunotherapy, potentiation and detoxification of anticancer drugs. Methods Find Exp Clin Pharmacol 1992, 14:725-736.

6. Liu J, Zhang JF, Lu JZ, Zhang DL, Li K, Su K, Wang J, Zhang YM, Wang N, Yang ST, Bu L, Ou-Yang JP: Astragalus polysaccharide stimulates glucose 
uptake in L6 myotubes through AMPK activation and AS160/TBC1D4 phosphorylation. Acta Pharmacol Sin 2013, 34(1):137-145.

7. Shao BM, Xu W, Dai H, Tu P, Li Z, Gao XM: A study on the immune receptors for polysaccharides from the roots of astragalus membranaceus, a Chinese medicinal herb. Biochem Biophys Res Commun 2004, 320:1103-1111.

8. Duan P, Wang ZM: Clinical study on effect of astragalus in efficacy enhancing and toxicity reducing of chemotherapy in patients of malignant tumor. Zhongguo Zhong Xi Yi Jie He Za Zhi 2002, 22:515-517.

9. Liu J, Chen HB, Guo BL, Zhao ZZ, Liang ZT, Yi T: Study of the relationship between genetics and geography in determining the quality of astragali radix. Biol Pharm Bull 2011, 34(9):1404-1412.

10. Wang Y, Qian XJ, Hadley HR, Lau BH: Phytochemicals potentiate interleukin-2 generated lymphokine-activated killer cell cytotoxicity against murine renal cell carcinoma. Mol Biother 1992, 4:143-146.

11. Liu J, Hu X, Yang Q, Yu Z, Zhao Z, Yi T, Chen H: Comparison of the immunoregulatory function of different constituents in radix astragali and radix hedysari. J Biomed Biotechnol 2010, 2010:479426.

12. Zheng Z, Liu D, Song C, Cheng C, Hu Z: Studies on chemical constituents and immunological function activity of hairy root of astragalus membranaceus. Chin J Biotechnol 1998, 14(2):93-97.

13. Wang YP, Li XY, Song CQ, Hu ZB: Effect of astragaloside IV on T, B lymphocyte proliferation and peritoneal macrophage function in mice. Acta Pharmacol Sin 2002, 23:263-266.

14. Zhang WD, Chen H, Zhang C, Liu RH, Li HL, Chen HZ: Astragaloside IV from Astragalus membranaceus shows cardioprotection during myocardial ischemia in vivo and in vitro. Planta Med 2006, 72:4-8.

15. Zhang BQ, Hu SJ, Qiu LH, Shan QX, Sun J, Xia Q, Bian K: Diphasic effects of Astragalus membranaceus BUNGE (Leguminosae) on vascular tone in rat thoracic aorta. Biol Pharm Bull 2005, 28(8):1450-1454.

16. Tin MMY, Cho CH, Chan K, James AE, Ko JKS: Astragalus saponins induce growth inhibition and apoptosis in human colon cancer cells and tumor xenograft. Carcinogenesis 2007, 28:1347-1355.

17. Kathy KW: Auyeung1, Chi-Hin Cho2 and Joshua K.S. Ko A novel anticancer effect of astragalus saponins: transcriptional activation of ) NSAID-activated gene. Int I Cancer 2009, 125:1082-1091.

18. Ma XQ, Shi Q, Duan JA, Dong TT, Tsim KW: Chemical analysis of radix astragali (Huangqi) in China: a comparison with its adulterants and seasonal variations. J Agric Food Chem 2002, 50(17):4861-4866.

19. Yang B, Xiao B, Sun T: Antitumor and immunomodulatory activity of astragalus membranaceus polysaccharides in $\mathrm{H} 22$ tumor-bearing mice. Int J Biol Macromol 2013, 62C:287-290.

20. Wu JJ, Sun WY, Hu SS, Zhang S, Wei W: A standardized extract from paeonia lactiflora and astragalus membranaceus induces apoptosis and inhibits the proliferation, migration and invasion of human hepatoma cell lines. Int J Oncol 2013, 43(5):1643-1651.

21. Shan L, Ying J, Lu N: HER2 expression and relevant clinicopathological features in gastric and gastroesophageal junction adenocarcinoma in a Chinese population. Diagn Pathol 2013, 8:76-83.

22. Jin J, Jin T, Quan M Piao Y, Lin Z: Ezrin overexpression predicts the poor prognosis of gastric adenocarcinoma. Diagn Pathol 2012, 7:135-148.

23. Sotoudeh K, Hashemi F, Madjd Z, Sadeghipour A, Molanaei S, Kalantary E: The clinicopathologic association of c-MET overexpression in Iranian gastric carcinomas; an immunohistochemical study of tissue microarrays. Diagn Pathol 2012, 7:57-62

24. Jia R, Cao L, Xu P, Jeney G, Yin G: In vitro and in vivo hepatoprotective and antioxidant effects of astragalus polysaccharides against carbon tetrachloride-nduced hepatocyte damage in common carp (cyprinus carpio). Fish Physiol Biochem 2012, 38(3):871-881.

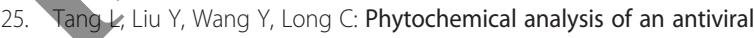
fraction of Radix astragali using HPLC-DAD-ESI-MS/MS. J Nat Med 2010, 64(2):182-186

26. Karimi P, Khavari-Nejad RA, Niknam V, Ghahremaninejad F, Najafi F: The effects of excess copper on antioxidative enzymes, lipid peroxidation, proline, chlorophyll, and concentration of $\mathrm{Mn}, \mathrm{Fe}$, and $\mathrm{Cu}$ in Astragalus neo-mobayenii. Sci World J 2012, 2012:615670.

27. Cui R, He J, Wang B, Zhang F, Chen G, Yin S, Shen H: Suppressive effect of astragalus membranaceus Bunge on chemical hepatocarcinogenesis in rats. Cancer Chemother Pharmacol 2003, 51:75-80.
28. Kim W, Kim SH, Park SK, Chang MS: Astragalus membranaceus ameliorates reproductive toxicity induced by cyclophosphamide in male mice. Phytother Res 2012, 26(9):1418-1421.

29. Rittenhouse JR, Lui PD, Lau BH: Chinese medicinal herbs reverse macrophage suppression induced by urological tumors. J Urol 1991, 146(2):486-490.

30. Zhao XZ: Effects of astragalus membranaceus and tripterygium hypoglancum on natural killer cell activity of peripheral blood mononuclear in systemic lupus erythematosus. Zhongguo Zhong Xi Yi Jie He Za Zhi 1992, 12(11):669-671.645

31. Shiner RJ, Schofield E, Bates PA, Waelkens E, Dallman M, Lamb y, Zicha D. Downward J, Seckl MJ, Pardo OE: A siRNA screen identifies RSK1 as a key modulator of lung cancer metastasis. Oncogene 2011, 30(32):3513-3521.

32. Gawecka JE, Young-Robbins SS, Sulzmaier FJ, Caliva MJ, Heikkilä MM, Matter ML, Ramos JW: RSK2 protein suppresses integrin activation and fibronectin matrix assembly and promotes cell migration. J Biol Chem 2012, 287(52):43424-43437.

33. van Jaarsveld MT, Blijdorp IC, Boersma AW, Pothof J, Mathijssen RH, Verweij J, Wiemer EA: The kinase RSK2 modulates the sensitivity of ovarian cancer cells to cisplatin. Eur J Cancer 2013, 49(2):345-351.

34. Eisinger-Mathason TS, Andrade N, Lannigan DA.RSK in tumorigenesis: connections to steroid signaling. Steroids 2010, 75(3):191-202.

35. Hilinski MK, Mrozowski RM, Clark DE, Lannigan DA: Analogs of the RSK inhibitor SL0101: optimization of in vitro biological stability. Bioorg Med Chem Lett 2012, 22(9):3244-3247.

36. Cho YY, Lee MA, Lee CJ, Yao K, Lee HS, Bode AM, Dong Z: RSK2 as a key regulator in human skin cancer. Carcinogenesis 2012, 33(12):2529-2537.

37. Peng C, Zhu F, Wen W, Yao K, Li S, Zykova T, Liu K, Li X, Ma WY, Bode AM, Dong Z: Tumor necrosis factor receptor-associated factor family protein 2 is a key mediator of the epidermal growth factor-induced ribosomal S6 kinase 2/CAMP-responsive element-binding protein/Fos protein signaling pạthway. J Biol Chem 2012, 287(31):25881-25892.

doi:10.1186/1746-1596-8-179

Cite this article as: Wang et al: Astragalus saponins affect proliferation

invasion and apoptosis of gastric cancer BGC-823 cells. Diagnostic Pathology 2013 8:179

\section{Submit your next manuscript to BioMed Central and take full advantage of:}

- Convenient online submission

- Thorough peer review

- No space constraints or color figure charges

- Immediate publication on acceptance

- Inclusion in PubMed, CAS, Scopus and Google Scholar

- Research which is freely available for redistribution 